\title{
THE EFFECTS OF A 6 WEEK PLYOMETRIC TRAINING PROGRAMME ON EXPLOSIVE STRENGTH AND AGILITY IN PROFESSIONAL BASKETBALL PLAYERS
}

\author{
Michal Lehnert ${ }^{1, *}$, Karel Hůlka ${ }^{1}$, Tomáš Malý ${ }^{2}$ Jaroslav Fohler ${ }^{1}$, František Zahálka²
}

${ }^{1}$ Faculty of Physical Culture, Palacký University, Olomouc, Czech Republic

${ }^{2}$ Faculty of Physical Education and Sport, Charles University, Prague, Czech Republic

Submitted in September, 2013

\begin{abstract}
BACKGROUND: Explosive strength of the lower extremities and agility are important parts of game performance in basketball. Although numerous studies have focused on the assessment of the training effect of plyometric training, studies focusing on elite players are missing.

OBJECTIVE: The aim of the study was to find out what changes in explosive strength of the lower extremities take place after a 6 week plyometric training applied in training units during the pre-season in elite basketball players.

METHODS: Elite basketball players $(N=12$, age $24.36 \pm 3.9$ years, height $196.2 \pm 9.6 \mathrm{~cm}$, weight $92.9 \pm 13.9 \mathrm{~kg})$ performed a 6 week plyometric training (PT) programme predominantly focused on explosive strength of the lower body and upper body and was conducted in sixteen training units during pre-season. The changes in explosive strength were measured by the Counter Movement Jump Free Arms test and Two Step Run Up Jump test; agility was measured using the "T" Drill test and Hexagonal Obstacle test. The players participated in three measurements. The 1st (pretesting) was performed on the first day of pre-season, the 2nd (post-testing) was done two days after completing the PT programme and the 3rd (post-testing) six weeks after completing the PT programme. Friedman's ANOVA for repeated measurements was used to determine the significance of differences between the measurement sessions $(p<.05)$.
\end{abstract}

RESULTS: A significant effect of the training programme was observed only for the Hexagonal Obstacle test $(p=.01)$. A post hoc analysis revealed a significant increase in test performance between the 1 st and 3 rd measurement $(p<.01)$ and between the 2nd and 3rd measurement $(p<.01)$.

CONCLUSIONS: The results of the study of elite basketball players did not positively support the assumption that plyometric exercises can be an effective tool for the improvement of explosive strength and agility. However, in some players the improvements corresponded to average improvements after training programmes presented in literature.

Keywords: Periodization, power, team games, testing.

\section{INTRODUCTION}

Basketball is a multifaceted and complex intermittent team sport that combines cyclic and acyclic movements (Erčulj, Blas, \& Bračič, 2010). Although basketball performance requires good aerobic capacity for recovery after high-intensity activity, many authors agree that the nature of basketball performance lies in anaerobic capacity (Delextrat \& Cohen, 2009). Many changes of speed, type of locomotion, direction and a lot of jumps that occur during the game require quickness and power development in training.

Plyometric training (PT) is ranked among the most frequently used methods for the development of the

\footnotetext{
* Address for correspondence: Michal Lehnert, Department of Sport, Faculty of Physical Culture, Palacký University, tř. Míru 115, 77111 Olomouc, Czech Republic. E-mail: michal.lehnert@upol.cz
}

above mentioned characteristics in team games and is also included in rehabilitation programmes (Shiner, Bishop, \& Cosgarea, 2005). The results of research have confirmed that PT can enhance muscle strength and power (Fleck \& Kraemer, 2004; Markovic, Jukić, Milanović, \& Metikoš, 2007; Soundara \& Pushparajan, 2010), speed and agility (Kotzamanidis, 2006; Miller, Herniman, Ricard, Cheatham, \& Michael, 2006; Schmidtbleicher \& Wirth, 2006) and running economy (Turner, 2003). These abilities are the essential skills in many team games including basketball because they enable players to perform activities during the game at the required height, speed and at the right moment (Gamble, 2010).

Plyometric exercises consist of a rapid eccentric action immediately followed by a concentric action of the muscle and connective tissue aiming at the development of maximum force in the shortest possible time 
(Bosco, 1985; Potach \& Chu, 2008). This regime of muscle contractions called the stretch-shortening cycle (SSC) is a typical part of muscle activity in a number of specific basketball activities such as acceleration, changing the direction of running, vertical jump (shooting, blocking, rebounding), passing.

PT leads to an adaptation of CNS for a faster development of reaction strength during work and for improved utilization of elastic energy generated in elastic elements of the muscle tissue and tendons during the stretching phase of SSC (Bosco, 1985; Ishikawa \& Komi, 2003; Potach \& Chu, 2008). Cormie, Guigan, and Newton (2011) clarify the interactions between the contractile and elastic elements and point out that their different length-shortening behaviour is vital in SSC movements. Moreover, the power/strength produced during the initial phase of the stretch-shortening cycle positively influences neuromuscular control and joint stabilization. From this point of view, decreased inhibition of muscle reflex, increased threshold of Golgi receptors, and improved sensitivity of neuromuscular spindles are the most important adaptations (Bompa \& Carrera, 2005; Boyle, 2004).

Except basic PT principles, a PT programme should consider the goal of training for a particular period, competitions, possible combination with other training exercises, jump load and actual health condition. Preparatory strength training is often recommended (Gambetta, 1998; Harley \& Doust, 1997; Komi, 1992; Potach \& Chu, 2008). A PT programme should also respect basic training principles including the principle of specificity (Bompa \& Carrera, 2005) and different types of stretch shortening cycles (Schmidtbleicher \& Wirth, 2006). From the point of view of the lower extremities, PT employs various modifications of specific jumping exercises (Chu, 1998; Radcliffe \& Farentinos, 1999) but also starts, stops and changes of direction in an explosive manner, which are a part of agility development (Craig, 2004).

Numerous studies have discovered the effects of short-term PT on jumping performance in basketball (Brown, Mayhew, \& Boleach, 1986; Matavulj, Kukolj, Ugarkovic, Tihanyi, \& Jaric, 2001), soccer (Faigenbaum \& Wayne, 2001; Thomas, French, \& Gates, 2009), volleyball (Fry, Kraemer, Weseman, Conroy, \& Gordon, 1991; Martel, Harmer, Logan, \& Parker, 2005; Milič, Nejic, \& Kostic, 2008) and other team games. Based on a meta-analysis of the studies, Marković et al. (2007) came to conclusion that PT provides statistically significant and practically relevant data in vertical jump height ranging from $4.7 \%$ to $8.7 \%$ depending on the jump type. The author pointed out that the most important factor responsible for the discrepancy among the results published in literature is the sample size used in training interventions. In a similar research study, Villarreal, Eleftherios, Kraemer, and Izquerdo (2009) claim improvements in vertical jumps height from 4.7 to $15 \%$, however in some studies no effects were observed (Herrero, Izquierdo, Maffiuletti, \& García-López, 2006; Miller, Berry, Bullard, \& Gilder, 2002). Although numerous studies have focused on the assessment of a training effect of PT, studies focusing on elite male basketball players are missing. Therefore, the aim of the study was to find out what changes in explosive strength of the lower extremities take place after a 6 week PT applied in training units (TUs) during pre-season in elite basketball players.

\section{METHODS}

\section{Subjects}

The study involved a group of basketball players $(N=12$, age $24.36 \pm 3.9$ years, height $196.2 \pm 9.6 \mathrm{~cm}$, weight $92.9 \pm 13.9 \mathrm{~kg}$ ) who played in the Czech first league. Before the commencement of training during the off-season, the players were informed about the principles of the plyometric exercises and became familiar with the techniques of exercises to be used in pre-season and also about the content of the test procedures. Before the commencement of the PT programme the players were informed about the aim and methods of the research and agreed with their participation in the research and the use of observed data for research purposes.

\section{Training programme}

During the 6 weeks of pre-season the players participated in two TUs a day, five days a week in total. PT programme was predominantly focused on the power of the lower body and upper body and was conducted in 16 TUs immediately after warm-up. The group of players participated in three successive parts of the PT programme: A, B and C (Table 1-3) that contained different types of plyometric exercises (Chu, 1998; Radcliffe \& Farentinos, 1999; Villareal et al., 2009) and were designed to account for specific requirements of basketball performance, intensity of plyometric exercises and other PT requirements. The rest period between individual exercises was two minutes. PT was applied two days per week (Monday and Thursday) from the 1 st to 4 th week and on four days per week from the 5 th to 6 th week. In the last two weeks plyometric exercises of the lower body were combined with resistance exercises of the upper body and vice versa in one day. The number of jumps gradually increased throughout the training programme and ranged as follows for individual parts of the PT programme: A 84-150, B 62-138 and C 44-96 jumps. Apart from PT, the training programme during pre-season further included resistance training with $60-80 \% 1 \mathrm{RM}$ (16 TUs), athletic train- 
Table 1

Plyometric training programme during 1st-4th week

\begin{tabular}{|c|c|c|c|c|c|c|c|c|}
\hline & \multicolumn{2}{|c|}{ W1 } & \multicolumn{2}{|c|}{ W2 } & \multicolumn{2}{|c|}{ W3 } & \multicolumn{2}{|c|}{ W4 } \\
\hline & REP & $S$ & REP & $\mathrm{S}$ & REP & $S$ & REP & $S$ \\
\hline \multicolumn{9}{|l|}{ Part A } \\
\hline Pogo jump & 10 & 3 & 10 & 3 & - & - & 10 & 3 \\
\hline Rim jump & $4-6$ & 3 & $4-6$ & 3 & - & - & $6-8$ & 3 \\
\hline Side hop-sprint (height of obstacle $30 \mathrm{~cm}$ ) & $6-8$ & 3 & $6-8$ & 3 & - & - & $8-10$ & 3 \\
\hline Lateral bound single response (each leg) & $4-6$ & 3 & $4-6$ & 3 & - & - & $6-8$ & 3 \\
\hline Plyometric push ups & $3-5$ & 3 & $3-5$ & 3 & & & $4-6$ & 3 \\
\hline Medicine ball chest pass both hand & $8-12$ & 1 & $8-12$ & 1 & - & - & $10-12$ & 1 \\
\hline Medicine ball chest pass right hand & $8-12$ & 1 & $8-12$ & 1 & - & - & $10-12$ & 1 \\
\hline Medicine ball chest pass left hand & $8-12$ & 1 & $8-12$ & 1 & - & - & $10-12$ & 1 \\
\hline \multicolumn{9}{|l|}{ Part B } \\
\hline Knee-tuck jump & $4-6$ & 3 & - & - & $4-6$ & 3 & $6-8$ & 3 \\
\hline Split jump (each leg) & $4-6$ & 2 & - & - & $4-6$ & 3 & $6-8$ & 3 \\
\hline Side hop (height of cone $40 \mathrm{~cm}$ ) & $6-8$ & 3 & - & - & $6-8$ & 3 & $8-10$ & 3 \\
\hline Single-leg lateral hop (each leg; obstacle $30 \mathrm{~cm}$ ) & $4-6$ & 2 & - & - & $4-6$ & 3 & $4-6$ & 3 \\
\hline Medicine ball half twist (each side) & $6-8$ & 2 & - & - & $8-10$ & 2 & $8-10$ & 2 \\
\hline Medicine ball full twist (each side) & $6-8$ & 2 & - & - & $8-10$ & 2 & $8-10$ & 2 \\
\hline \multicolumn{9}{|l|}{ Part C } \\
\hline Scissors jump & - & - & $4-6$ & 2 & $4-6$ & 4 & - & - \\
\hline Alternate leg diagonal bound & - & - & $4-6$ & 3 & $6-8$ & 3 & - & - \\
\hline Double-leg hop progression (hurdle height $50 \mathrm{~cm}$ ) & - & - & $4-6$ & 3 & $6-8$ & 3 & - & - \\
\hline Depth jump to the rim (box height $35 \mathrm{~cm}$ ) & - & - & $4-6$ & 3 & $6-8$ & 3 & - & - \\
\hline Medicine ball twist toss (each side) & - & - & $6-8$ & 2 & $8-10$ & 2 & - & - \\
\hline Sit-up throw & - & - & $6-8$ & 3 & $8-10$ & 3 & - & - \\
\hline
\end{tabular}

Note. W1-4 = number of training week in preseason, $\mathrm{REP}=$ number of repetitions $/$ set, $\mathrm{S}=$ number of sets.

ing including speed exercises and aerobic endurance (16 TUs), skill-based training (37 TUs) and warm-up matches (9 TUs).

\section{Testing procedures}

The tests were selected according to the type of the training programme and requirements of game performance. The players participated in three testing sessions. The 1st measurement (pretesting) was performed on the first day of pre-season, the 2 nd (posttesting) was done two days after terminating the PT programme and the 3rd (post-testing) six weeks after terminating the PT programme, during in-season. The testing was always performed in the morning training units and the players were motivated by the coach to reach maximum performance. High-intensity exercises were excluded from the training programme two days before the testing sessions.

Explosive strength of the lower extremities was assessed by means of the Counter Movement Jump Free
Arms (CMJFA) and Two Step Run Up Jump (TSRUJ) tests. In both cases the result of the test was the best performance $(\mathrm{cm})$ out of three successful attempts. The rest period between individual attempts was $30 \mathrm{~s}$. Vertical jump performance was assessed using a portable optical timing system (Optojump Next, Microgate, Bolzano, Italy) with manufacturer-declared accuracy of $0.001 \mathrm{~s}$ ). This instrument consists of two bars (active - transmitting, passive - receiving) with 33 optical LEDs. Provided that the time period between take-off and reaching maximum height equals the time period between maximum height and landing, jump height was calculated from jump duration as $h=1 / 8 \cdot g t^{2}$, where $h$ is jump height, $g$ is gravitational constant and $t$ is flight time.

Agility was measured using the "T" Drill test (TDT), which is considered the most used agility test (Delextrat \& Cohen, 2009; Semenick, 1990; Sporis, Jukic, Milanovic, \& Vucetic, 2010), and Hexagonal Obstacle test (HOT) (Harman \& Garhammer, 2008; Mac- 
Table 2

Training programme during 5th week (PT combined with resistance training)

\begin{tabular}{|c|c|c|c|c|}
\hline Day & Content & Exercise & REP & $\mathrm{S}$ \\
\hline \multirow[t]{10}{*}{ Monday } & \multirow[t]{4}{*}{ Plyometrics } & Scissors jump & $4-6$ & 2 \\
\hline & & Depth jump to the rim & $4-6$ & 3 \\
\hline & & Double-leg hop progression (hurdle $50 \mathrm{~cm}$ ) & $4-6$ & 3 \\
\hline & & Alternate leg diagonal bound & 6.8 & 3 \\
\hline & \multirow[t]{6}{*}{ Resistance training } & Lat pull down & 10 & 3 \\
\hline & & Pull ups & $4-8$ & 3 \\
\hline & & Power clean & 6 & 3 \\
\hline & & Military press & 8 & 3 \\
\hline & & Dumbbell side bends (each side) & 10 & 3 \\
\hline & & Sit-up variation & $40-60$ & 3 \\
\hline \multirow[t]{9}{*}{ Tuesday } & \multirow[t]{4}{*}{ Plyometrics } & Plyometrics push ups & $3-5$ & 3 \\
\hline & & Medicine ball half twist & $6-8$ & 2 \\
\hline & & Medicine ball full twist & $6-8$ & 2 \\
\hline & & Sit-up throw & $8-10$ & 3 \\
\hline & \multirow[t]{5}{*}{ Resistance training } & Leg press & 10 & 3 \\
\hline & & Calf raises & 20 & 3 \\
\hline & & Lateral squat (each side) & $4-6$ & 3 \\
\hline & & Leg extension & 10 & 3 \\
\hline & & Hamstring curl & 10 & 3 \\
\hline \multirow[t]{10}{*}{ Thursday } & \multirow[t]{4}{*}{ Plyometrics } & Pogo jump & 10 & 3 \\
\hline & & Knee-tuck jump & $4-6$ & 3 \\
\hline & & Lateral bound single response (each leg) & $6-8$ & 3 \\
\hline & & Side hop & $6-8$ & 3 \\
\hline & \multirow[t]{6}{*}{ Resistance training } & Bench press & 10 & 3 \\
\hline & & Push press & 8 & 3 \\
\hline & & Triceps dips & $6-8$ & 3 \\
\hline & & Triceps pushdowns & 10 & 3 \\
\hline & & Hammer dumbbell curls & 10 & 3 \\
\hline & & Sit-up variation & $40-60$ & 3 \\
\hline \multirow[t]{9}{*}{ Friday } & \multirow[t]{4}{*}{ Plyometrics } & Medicine ball chest pass both hand & $8-10$ & 3 \\
\hline & & Medicine ball chest pass right hand & $8-10$ & 3 \\
\hline & & Medicine ball chest pass left hand & $8-10$ & 3 \\
\hline & & Medicine ball twist toss (each side) & $8-10$ & 2 \\
\hline & \multirow[t]{5}{*}{ Resistance training } & Front squat & $4-6$ & 3 \\
\hline & & Back squat & $4-6$ & 3 \\
\hline & & Lunges & 10 & 3 \\
\hline & & Dumbbell step up & 10 & 3 \\
\hline & & Calf raises & 20 & 3 \\
\hline
\end{tabular}

Note. $\quad \mathrm{REP}=$ number of repetitions/set, $\mathrm{S}=$ number of sets. 
Table 3

Training programme during 6th week (PT combined with resistance training)

\begin{tabular}{|c|c|c|c|c|}
\hline Day & Content & Exercise & REP & $\mathrm{S}$ \\
\hline \multirow[t]{10}{*}{ Monday } & \multirow[t]{4}{*}{ Plyometrics } & Scissors jump & $4-6$ & 2 \\
\hline & & Depth jump to the rim (box height $35 \mathrm{~cm}$ ) & $6-8$ & 3 \\
\hline & & Side hop-sprint & $8-10$ & 3 \\
\hline & & Single-leg lateral hop (each leg) & $6-8$ & 3 \\
\hline & \multirow[t]{6}{*}{ Resistance training } & Lat pull down & 10 & 3 \\
\hline & & Pull ups & $4-8$ & 3 \\
\hline & & Power clean & 6 & 3 \\
\hline & & Military press & 8 & 3 \\
\hline & & Dumbbell side bends (each side) & 10 & 3 \\
\hline & & Sit-up variation & $40-60$ & 3 \\
\hline \multirow[t]{9}{*}{ Tuesday } & \multirow[t]{4}{*}{ Plyometrics } & Plyometrics push ups & $4-6$ & 3 \\
\hline & & Medicine ball half twist & $8-10$ & 4 \\
\hline & & Medicine ball full twist & $8-10$ & 4 \\
\hline & & Sit-up throw & $8-12$ & 3 \\
\hline & \multirow[t]{5}{*}{ Resistance training } & Leg press & 10 & 3 \\
\hline & & Calf raises & 20 & 3 \\
\hline & & Lateral squat (each side) & 6.8 & 3 \\
\hline & & Leg extension & 10 & 3 \\
\hline & & Hamstring curl & 10 & 3 \\
\hline \multirow[t]{10}{*}{ Thursday } & \multirow[t]{4}{*}{ Plyometrics } & Split jump (each leg) & $6-8$ & 3 \\
\hline & & Rim jump & $6-8$ & 3 \\
\hline & & Double-leg hop progression & $4-6$ & 3 \\
\hline & & Alternate leg diagonal bound & $8-10$ & 3 \\
\hline & \multirow[t]{6}{*}{ Resistance training } & Bench press & 10 & 3 \\
\hline & & Push press & 8 & 3 \\
\hline & & Triceps dips & $8-10$ & 3 \\
\hline & & Triceps pushdowns & 10 & 3 \\
\hline & & Hammer dumbbell curls & 10 & 3 \\
\hline & & Sit-up variation & $40-60$ & 3 \\
\hline \multirow[t]{9}{*}{ Friday } & \multirow[t]{4}{*}{ Plyometrics } & Medicine ball chest pass both hand & $10-12$ & 3 \\
\hline & & Medicine ball chest pass right hand & $10-12$ & 3 \\
\hline & & Medicine ball chest pass left hand & $10-12$ & 3 \\
\hline & & Medicine ball twist toss (each side) & $10-12$ & 2 \\
\hline & \multirow[t]{5}{*}{ Resistance training } & Front squat & $6-8$ & 3 \\
\hline & & Back squat & $6-8$ & 3 \\
\hline & & Lunges & 10 & 3 \\
\hline & & Dumbbell step up & 10 & 3 \\
\hline & & Calf raises & 20 & 3 \\
\hline
\end{tabular}

Note. $\mathrm{REP}=$ number of repetitions $/$ set, $\mathrm{S}=$ number of sets. 
kenzie, 2002). In both cases the results of the test was the better performance out of two successful attempts; recovery time between the first and second attempt was 3 minutes and 5 minutes respectively. In case of TDT, measurement was performed using the Optojump Next device, time in TDT was recorded using photocell gates (Brower Timing System, Salt Lake City, UT, USA, accuracy of $0.01 \mathrm{~s}$ ) placed $0.4 \mathrm{~m}$ above the ground. The first part of the warm-up was performed individually, the second part (specific) was coach supervised.

\section{Statistical analysis}

Statistical analysis was performed using the data analysis software system Statistica, version 10 (StatSoft, Inc., Tulsa, OK, USA). Friedman's ANOVA for repeated measurements was used to determine the significance of differences between the measurement sessions $(p<.05)$. The statistical significance of the differences between the results of particular measurements was verified by Wilcoxon paired test. Effect size was assessed by $\eta^{2}$ calculated as $\eta^{2}=\chi^{2} \cdot n^{-1} \cdot d f^{-1}$, where $\chi^{2}$ is chi-square, $n$ is the number of measurements, $d f$ is degrees of freedom (Morse, 1999; Xitao, 2001).

\section{RESULTS}

The average results of all tests can be seen in Table 4. A significant training effect was observed only for HOT $\left(\chi^{2}=11.56, p=.01, \eta^{2}=.64\right)$, while significant effect of the training programme was not observed in case of CMJFA $\left(\chi^{2}=2.29, p=.32, \eta^{2}=.13\right)$, TSRUJ $\left(\chi^{2}=2.31\right.$, $\left.p=.32, \eta^{2}=.13\right)$ and TDT $\left(\chi^{2}=3.16, p=.21, \eta^{2}=.18\right)$. In case of HOT, a post hoc analysis revealed a significant increase in test performance from the 1 st to $3 \mathrm{rd}$ measurement $(p<.01)$ and from the 2 nd to 3 rd measurement $(p<.01)$.

\section{DISCUSSION}

According to current knowledge (Marković et al., 2007; Villarreal et al., 2009), we expected that the PT applied systematically during six weeks would induce an increase in the parameters observed. In spite of this expectation, the basketball players in this study, undergoing plyometric training programme in a frequency of two days a week during the 6 week pre-season training programme, did not significantly enhance the mean values of the variables observed.

The only exception was HOT where an increasing tendency (pre-training, post-training and six weeks after finishing the 6 week PT) was observed. Contrary to other test results, the results of HOT showed a significant increasing tendency in performance between the 1 st and 3rd measurement by $7.8 \%$ and also between the 2nd and 3rd measurements by $5.6 \%$. HOT contains two footed back and forth jumps over the sides of a hexagon. Therefore we assume that the improvement in the 3rd measurement could be influenced by rope jumping exercises applied as the only type of plyometric exercise following the PT programme. The movement pattern of the jumps in both exercises is very similar and thus the probability of transfer of the training effect to the performance in HOT is high.

There could be several reasons for the absence of significant changes in explosive strength associated with the performance in CMJFA and agility associated with TDT. It is known that the training effects completing a PT programme are influenced by the subject characteristics, in particular training level, sport activity, age, gender, familiarity with plyometric exercises, level, programme design (programme duration, volume, rest periods, frequency, type of exercises and their combination, intensity of exercises, resistance etc.), (Villarreal et al., 2009). It is possible that the training duration of 6 weeks was too short to improve muscular functions due to a high training status of the elite players. However, the general recommendation stated 6-10 weeks of systematic application of PT to improve muscular strength and power (Potach \& Chu, 2008). A positive significant relation $(p<.05)$ between the programme duration, number of sessions and number of jumps per session and PT effect has been confirmed and PT lasting 10 weeks or more (more than 20 sessions in total) has been recommended to maximize the probability of

Table 4

Average test results in particular measurement sessions

\begin{tabular}{lcrrr}
\hline Test & $n$ & $M_{1} \pm S D_{1}$ & $M_{2} \pm S D_{2}$ & \multicolumn{1}{c}{$M_{3} \pm S D_{3}$} \\
\hline CMJFA (cm) & 12 & $48.15 \pm 4.57$ & $49.42 \pm 4.51$ & $48.13 \pm 5.68$ \\
TSRUJ (cm) & 10 & $52.94 \pm 4.81$ & $54.05 \pm 4.90$ & $53.97 \pm 7.42$ \\
TDT (s) & 11 & $9.35 \pm 0.49$ & $9.15 \pm 0.45$ & $9.42 \pm 0.40$ \\
HOT (s) & 10 & $9.52 \pm 0.76$ & $9.30 \pm 0.69$ & $8.78 \pm 0.51$ \\
\hline
\end{tabular}

Note. $\quad$ CMJFA $=$ Counter Movement Jump Free Arms, TSRUJ = Two Step Run Up Jump, TDT = "T" Drill Test; HOT = Hexagonal Obstacle Test, $M_{1} \pm S D_{1}=$ mean \pm standard deviation of measurement before 6 week PT, $M_{2} \pm S D_{2}=$ mean \pm standard deviation of measurement after 6 week PT, $M_{3} \pm S D_{3}=$ mean \pm standard deviation of measurement six weeks after terminating PT. 
obtaining significant improvements (Villarreal et al., 2009). Our results support the idea of insufficient PT programme duration.

However, also shorter PT programmes have proved to be effective in groups of individuals of various physical fitness and sport experience and frequency of PT two times a week (Milič et al., 2008; Miller et al., 2006; Soundara \& Pushparajan, 2010). Also in basketball, Toth (2011) presented, for the same jump test as in our study, an average improvement of $3.1 \mathrm{~cm}$ and $5.5 \mathrm{~cm}$, respectively, in a group of elite senior players after completing a 6 week PT. Matavulj et al. (2001) noted an average increase in junior basketball players of $4.8 \mathrm{~cm}$ and $5.6 \mathrm{~cm}$, respectively, after a 6 week PT, but conducted three times/week.

Another reason for no significant changes in the test results could be the influence of other training stimuli. Although the opinions on training programmes of such character are not completely uniform (Fleck \& Kraemer, 2004; Fry, 2004; Smith, 2003; Wong, Chaouachi, Chamari, Dellal, \& Wisloff, 2010), it is suggested that the effectiveness of the strength and power training may be lowered. Oppositely, some studies (Fatouros et al., 2000; Rahimi \& Behpur, 2006; Wirth \& Schmidtbleicher, 2007) confirmed that for well-trained athletes the combination of resistance training and PT is more effective. Therefore it could be assumed that an intelligent combination of these methods in one training unit could bring more positive changes of explosive strength rather than their separate use during pre-season.

Concerning the worse results of the above mentioned tests recorded 6 weeks after PT termination, we could speculate that the cause could be a decrease in the volume of plyometric exercises and use of various rope jumps only in this period and subsequent partial loss of specific adaptations (Mujika \& Padilla, 2000a, $2000 \mathrm{~b}$ ). We could also speculate that lower motivation and concentration on testing sessions during competition period could be a cause of the worse test results.

In spite of the fact that there was no significant improvement in the average values in the monitored group, the highest individual increase in case of CMJFA and TSRUJ was $3.9 \mathrm{~cm}$ and $5.7 \mathrm{~cm}$ respectively (not mentioned in the text). These values roughly correspond to the average improvement after taking the PT programmes (Villarreal et al., 2009). On the other hand, we observed a decrease in vertical jump height (most significant decrease by $2.6 \mathrm{~cm}$ in CMJFA and by $5.3 \mathrm{~cm}$ in TSRUJ). These results pertained to the two oldest players on the team (thirty and thirty-four years old, the average age of the team was 24 years). Although these players undertook the PT programme, they experienced health problems which could have limited their approach to the PT sessions and the training effect.
When interpreting the training effect of the PT programme we have to take into account a high level of basketball-specific physical fitness of the players already before the commencement of the pre-season training. The limitations of the study were a small number of observed players and the absence of a control group.

\section{CONCLUSIONS}

In conclusion, the results of the current study showed that the 6 week pre-season training programme with plyometric exercises did not produce significant changes in average values of the vertical jump tests applied. In case of agility, various tendencies were observed in the results of the two tests applied. A significant improvement was revealed only in case of HOT, where the best result was noted six weeks after participating in the programme. The results of the study did not positively support the assumption that plyometric exercises applied during pre-season in elite basketball players can be an effective tool for an improvement in the explosive strength and agility. However in individual players changes of power of the lower extremities and agility were different and in some cases the improvements corresponded to average improvements after PT programmes presented in literature.

\section{ACKNOWLEDGMENT}

The study has been supported by the research grant from the Ministry of Education, Youth and Sports of the Czech Republic (No. MSM 6198959221) "Physical Activity and Inactivity of the Inhabitants of the Czech Republic in the Context of Behavioral Changes".

\section{REFERENCES}

Bompa, T., \& Carrera, M. (2005). Periodization training for sports (2nd ed.). Champaign, IL: Human Kinetics.

Bosco, C. (1985). Physiologische Betrauchtungen zum Explosivkrafttraining unter Hyperschwerkraftbendingungen [Physiological considerations for explosive strength training with superheavy load]. Leistungsport, 15(2), 19-24.

Boyle, M. (2004). Functional training for sports. Champaign, IL: Human Kinetics.

Brown, M. E., Mayhew, J. L., \& Boleach, L. W. (1986). The effect of plyometric training on the vertical jump of high school basketball players. Journal of Sports Medicine \& Physical Fitness, 26(1), 1-4.

Chu, D. A. (1998). Jumping into plyometrics. Champaign, IL: Human Kinetics. 
Cormie, P., McGuigan, M. R., \& Newton, R. U. (2011). Developing maximal neuromuscular power. Part 1 - Biological basis of maximal power production. Sports Medicine, 41, 17-38.

Craig, B. W. (2004). What is the scientific basis of speed and agility? Strength \& Conditioning Journal, 26(3), 13-14.

Delextrat, A., \& Cohen, D. (2009). Strength, power, speed, and agility of women basketball players according to playing position. Journal of Strength \& Conditioning Research, 23, 1974-1981.

Erčulj, F., Blas, M., \& Bračič, M. (2010). Physical demands on young elite European female basketball players with special reference to speed, agility, explosive strength, and take-offpower. Journal of Strength \& Conditioning Research, 24, 2970-2978.

Fatouros, I. G., Jamurtas, A. Z., Leontsindi, D. T., Aggelousis, N., Kostopoulos, N., \& Buckenmeyer, P. (2000). Evaluation of plyometric exercise training, weight training, and their combination on vertical jumping performance and leg strength. Journal of Strength \& Conditioning Research, 14, 470-476.

Fleck, S. J., \& Kraemer, W. (2004). Designing resistance training programs. Champaign, IL: Human Kinetics Publishers.

Fry, A. C. (2004). The role of resistance exercise intensity on muscle fibre adaptations. Sports Medicine, 34, 663-679.

Fry, A. C., Kraemer, W. J., Weseman, C. A., Conroy, B. P., \& Gordon, S. E. (1991). The effect of an offseason strength and conditioning programme on starters and non-starters in womens' intercollegiate volleyball. Journal of Strength \& Conditioning Research, 5, 174-181.

Gambetta, V. (1998). Plyometrics - myths and misconceptions. Sport Coach, 20(4), 7-12.

Gamble, P. (2010). Strength and conditioning for team sports: Sport specific physical preparation for high performance. London: Taylor \& Francis Group.

Harley, R., \& Doust, J. (1997). Strength and fitness training for basketball. Leeds: NFC Publications.

Harman, E., \& Garhammer, J. (2008). Administration, scoring, and interpretation of selected tests. In R. T. Beachle \& R. W. Earle (Eds.), Essentials of strength training \& conditioning (pp. 427-470). Champaign, IL: Human Kinetics.

Herrero, J. A., Izquierdo, M., Maffiuletti, N. A., \& García-López, J. (2006). Electromyostimulation and plyometric training effects on jumping and sprint time. International Journal of Sport Medicine, 27, 533-539.

Ishikawa, M., Finni, T., \& Komi, P. V. (2003). Behaviour of vastus lateralis muscle-tendon during high intensity SSC exercises in vivo. Acta Physiologica Scandinavica, 178, 205-213.
Komi, V. (1992). Strength and power in sport. Oxford: Blackwell Scientific Publications.

Kotzamanidis, C. (2006). Effect of plyometric training on running performance and vertical jumping in prepubertal boys. Journal of Strength \& Conditioning Research, 20, 441-445.

Mackenzie, B. (2002). Hexagonal Obstacle Test. Retrieved from http://www.brianmac.co.uk/hexagonal.htm

Marković, G., Jukić, I., Milanović, D., \& Metikoš, D. (2007). Effects of sprint and plyometric training on muscle function and athletic performance. Journal of Strength \& Conditioning Research, 21, 543-549.

Martel, G. F., Harmer, M. L., Logan, J. M., \& Parker, C. B. (2005). Aquatic plyometric training increases vertical jump in female volleyball players. Medicine \& Science in Sports \& Exercise, 37, 1814-1819.

Matavulj, D., Kukolj, M., Ugarkovic, D., Tihanyi, J., \& Jaric, S. (2001). Effects of plyometric training on jumping performance in junior basketball players. Journal of Sports Medicine \& Physical Fitness, 41, 159-164.

Milič, V., Nejic, D., \& Kostic, R. (2008). The effect of plyometric training on the explosive strength of leg muscles of volleyball players on single foot and two-foot take-off jumps. Physical Education \& Sport, 6, 169-179.

Miller, M. G., Berry, D. C., Bullard, S., \& Gilder, R. (2002). Comparisons of land-based and aquatic based plyometric programs during an 8 week training period. Journal of Sport Rehabilitation, 11, 268283.

Miller, M. G., Herniman, J. J., Ricard, M. D., Cheatham, C. C., \& Michael, T. J. (2006). The effects of a 6 week plyometric training programme on agility. Journal of Sports Science \& Medicine, 5, 459-465.

Morse, D. T. (1999). Minsize 2: A computer programme for determining effect size and minimum sample size for statistical significance for univariete, multivariete and nonparametric tests. Educational \& Psychological Measurement, 59, 518-531.

Mujika, I., \& Padilla, S. (2000a). Detraining: Loss of training - induced physiological and performance adaptations. Part I. Sports Medicine, 30, 79-87.

Mujika, I., \& Padilla, S. (2000b). Detraining: Loss of training - induced physiological and performance adaptations. Part II. Sports Medicine, 30, 145-154.

Potach, D. H., \& Chu, D. A. (2000). Plyometric training. In R. T. Beachle \& R. W. Earle (Eds.), Essentials of strength training \& conditioning (pp. 427-470). Champaign, IL: Human Kinetics.

Radcliffe, J. C., \& Farentinos, R. C. (1999). High powered plyometrics. Champaign, IL: Human Kinetics.

Rahimi, R., \& Behpur, N. (2005). The effect of polymetric - weight and training on anaerobic power 
and mucular strength. Facta Universitatis: Physical Education \& Sport, 3(1), 81-91.

Schmidtbleicher, D., \& Wirth, K. (2006). Comparison of different strength methods for the development of power. In H. Schwameder, G. Strutzenberger, V. Fastenbauer, S. Lindinger, \& E. Müller (Eds.), XXIV International Symposium on Biomechanics in Sport (pp. 306-310). Salzburg: University of Salzburg.

Semenick, D. (1990). The T-test. National Strength \& Conditioning Association Journal, 12, 36-37.

Shiner, J., Bishop, T., \& Cosgarea, A. J. (2005). Integrating low-intensity plyometrics into strength and conditioning programs. Strength \& Conditioning Journal, 27(6), 10-20.

Smith, D. J. (2003). A framework for understanding the training process leading to elite performance. Sports Medicine, 33, 1103-1126.

Sporis, G., Jukic, I., Milanovic, L., \& Vucetic, V. (2010). Reliability and factorial validity of agility tests for soccer players. Journal of Strength \& Conditioning Research, 24, 679-687.

Soundara, R., \& Pushparajan, A. (2010). Effect of plyometric training on the development the vertical jump in volleyball players. Journal of Physical Education \& Sport, 28(3), 65-69.

Thomas, K., French, D., \& Hayes, P. R. (2009). The effect of two plyometric training techniques on muscular power and agility in youth soccer players. Journal of Strength \& Conditioning Research, 23, 332-335.

Tóth, L. (2011). Zmèny explozivní síly u basketbalistů po absolvování prípravného období [Changes of explosive strength in basketball players after the pre-season training]. Bachelor thesis, Palacký University, Faculty of Physical Culture, Olomouc.

Turner, A., Owings, M., \& Schwane, J. A. (2003). Improvement in running economy after 6 weeks of plyometric training. Journal of Strength \& Conditioning Research, 17, 60-67.

Villareal, E. S., Eleftherios, E., Kraemer, W. J., \& Izquerdo, M. (2009). Determining variables of plyometric training for improving vertical jump height performance: A meta-analysis. Journal of Strength \& Conditioning Research, 23, 495-506.

Wong, P. L., Chaouachi, A., Chamari, K., Dellal, A., \& Wisloff, U. (2010). Effect of preseason concurrent muscular strength and high-intensity interval training in professional soccer players. Journal of Strength and Conditioning Research, 24, 653-660.

Xitao, F. (2001). Statistical significance and effect size in education research: Two sides of coin. The Journal of Educational Research, 94, 275-282.
Young, W. B. (2006). Transfer of strength and power training to sport performance. International Journal of Sports Physiology \& Performance, 1, 74-83.

\section{EFEKTY ŠESTITÝDENNÍHO PLYOMETRICKÉHO TRÉNINKOVÉHO PROGRAMU NA EXPLOZIVNÍ SÍLU A AGILITU PROFESIONÁLNÍCH BASKETBALISTU゚}

(Souhrn anglického textu)

VÝCHODISKA: Explozivní síla dolních končetin a agility jsou důležitými faktory herního výkonu v basketbale. Ačkoli se mnoho studí́ zabývalo stanovením tréninkového efektu plyometrického tréninku, existuje nedostatek studií zaměřených na vrcholové hráče.

CÍLE: Cílem studie bylo zjistit, jaké změny explozivní síly dolních končetin vrcholových basketbalistů nastanou po šestitýdenním plyometrickém tréninku v průběhu přípravného období.

METODIKA: Vrcholoví basketbaloví hráči $(N=12$; věk $24,36 \pm 3,9$ roků; tělesná výška $196,2 \pm 9,6 \mathrm{~cm}$; tělesná hmotnost 92,9 $\pm 13,9 \mathrm{~kg}$ ) absolvovali šestitýdenní plyometrický trénink, který byl převážně zaměřen na explozivní sílu dolní a horní části těla a byl zařazen v šesti tréninkových jednotkách přípravného období. Změny explozivní síly byly hodnoceny testem vertikální skok z místa a testem vertikální skok po dvoukrokovém rozběhu, $k$ měření agility byl využit „T-drill test“ a test „Šestiúhelník“. Hráči absolvovali tři měření. První (pretest) v den zahájení přípravného období, druhé dva dny po skončení plyometrického tréninku a třetí šest týdnů po jeho skončení.

VÝSLEDKY: Signifikantní efekt tréninkového programu byl pozorován pro test „Šestiúhelník“ $\left(\chi^{2}=11,56\right.$; $\left.p=0,01 ; \eta^{2}=0,64\right)$. Post hoc analýza ukázala na signifikantní nárůst testových skóre mezi prvním a třetím měřením a mezi druhým a třetím měřením $(p<0,01)$.

ZÁVĚRY: Výsledky studie u vrcholových basketbalistů plně nepotvrdily předpoklad, že plyometrická cvičení mohou být efektivním prostředkem rozvoje explozivní síly a agility. Nicméně zlepšení u některých hráčů korespondovalo $\mathrm{s}$ průměrným zlepšením po absolvování plyometrického tréninkového programu uváděným v literatuře.

Klićcová slova: periodizace, výbušnost, týmové sporty, testování. 